\title{
Nothing to Declare: Status, Power and Religious Aspiration in the Policies of Taxation in Ancient India
}

\author{
Ulrich Pagel*
}

This paper examines a group of legal, religious and commercial privileges connected with revenue collection in ancient Indian society. ${ }^{1}$ These privileges, I argue, derive from and reflect the standing of Buddhist monks in that period. Much of the discussion that follows centers around the Sangha's status in Indian tax law. It charts the factors that led Buddhist monks to call for tax immunity for the goods they carried on their travels across northern India. In this sense, the article is about money. But tax collection, although central to a state's financial health, is not exclusively informed by fiscal considerations. Some of the Buddhists' pleas for tax exemption sprang from privileges long held by their brahmanical peers. They clamoured for the very same rights that Indian political treatises (dharmaśástra) extended to brahmins and Hindu ascetics. Taxation is also a tool deployed to manage social privilege and economic division in society and hence reflects the values its rulers seek to promote. As a result, this investigation explores the ranking of the Buddhist community within the wider arena of religious proliferation in ancient India. It contributes then to this special issue through its focus on tax exemption.

Keywords: Buddhist Monasticism; Indian Buddhism; History of Buddhism; Economic History of Ancient India; Buddhism in Society; Buddhism and the State; Vinaya Studies

Many of the religious traditions that sprang up in India in the fifth/sixth century BCE came to compete for patronage and recruitment in a bid to enhance their influence among the population. The Sayanāsanavastu section of the Mūlasarvāstivāda vinaya (which constitutes the monastic code for the Buddhist monks and nuns of the Mūlasarvāstivāda School) records an encounter between the Buddha's followers and a group of competing mendicants where they argue about money. It is not their own money though. The funds belong to a lay supporter, Anāthapiṇḍada, who wishes to pay for a religious foundation. This person is very rich indeed: his profession is banking. He ranks among the earliest and most generous sponsors of the Buddhist community:

* Correspondence details: Ulrich Pagel, School of History, Religions and Philosophy, SOAS, London, WC1H OXG, UK.Email: up1@soas.ac.uk.

1 Much of the research that underpins this essay was first published in my 2014 book: Buddhist Monks in Tax Disputes. I would like to thank the editors of this volume for accepting the current contribution for inclusion in the proceedings of »Religious Exemption and the State 400-1300«, Sheffield University, 14th to 16th April 2016. 
The householder Anāthapiṇdada gave that piece of land to Prince Jeta. The Prince then had built an entrance hall of a temple (vihära) on that land for the Blessed One. Then, the followers of the other religious traditions came together, angry and annoyed, to confer: >The householder Anāthapindada has pledged to build a temple for the Blessed Oner. They decided to approach Anăthapindada and when they reached him, they said: 'Householder, you cannot have a vihāra built for the mendicant (śramaṇa) Gautama.؛ He replied: 'And why not? «We divided up the towns. Rājagrha belongs to the mendicant Gautama; Śrāvastī belongs to us.` Anāthapiṇdada retorted: `You may have divided up the towns, but not my personal property. I shall build religious foundations for whomever I please. $\iota^{2}$

The passage contains an example of the rivalry that existed between the Buddhists and their religious peers. Here they vied for sponsorship. Elsewhere we encounter competition in recruitment and political access. In order to avoid open conflict, the different groups had carved up the territory in which they sought to establish themselves. In this instance, the matter was resolved internally: the Buddhists prevailed since they went on to defeat their opponents in a display of miracles. In other cases, though, when consent was not achieved, conflicts of this type called for arbitration drawing on the secular authorities. It then fell to the king and his ministers to manage the proliferation of these groups.

They did so through various political and financial instruments. In fiscal matters, the state in ancient India was able to control the strength of the different traditions through taxation; it could extend privileges to one faction but withhold them from another. The brahmanical treatises of governance contain good evidence that this was common practice. Fiscal policies, in other words, were used as a means to influence the fortunes of the religious traditions that had sprung up in the 5th century BCE and later. Their enforcement, in turn, impacted on the individual. Revenue collection often took place in delicate situations dominated by displays of state power. Most Buddhist monks emerged from these encounters with their dignity intact. Others were less adept and slipped into situations of conflict, jeopardising both the repute of the Sangha and their personal safety.

In this essay, I examine the ways in which the Sangha responded to such pressures. To begin with, I chart the monks' fiscal obligations, introducing the principles that governed taxation in ancient India and sketching their application. For this, I turn primarily to brahmanical legal treatises, such as the Arthaśästra, Mãnava Dharmaśästra and a number of connected sources. The dates of these texts have been much debated, but Olivelle, in an article devoted to this very subject, proposed the following chronology for the key works which I use here: Mānava Dharmaśästra: 2nd cent CE; Nāradasmṛti: 5/6th cent. CE; Vaiṣnava Dharmaśástra: 7th cent. CE; Yãjñavalkyasmrti: 4/5th cent. CE; and, perhaps most importantly, the Arthaśästra of Kauțalya/Viṣnugupta: $3 \mathrm{rd} / 4$ th cent. CE. ${ }^{3}$ These early legal treatises, more often than not, group the Buddhists together with other heterodox communities (Jains, Ajivakas, etc.). Some subsume the Buddhist monks in one (or more) of the classic genres of Indian religious practitioners: renunciants (pravrajita/parivräjaka), ascetics (tapasvin) or mendicants (bhikșu). In doing so, they deny them a separate identity and withhold from them a distinct 
status in law.

Most of the Buddhist material on tax liability appears in the Vinayavibhanga section of the Mūlasarvāstivāda vinaya, already quoted above. This text records a series of incidents where monks run into difficulty during customs inspections. The date of the Mūlasarvāstivāda vinaya has yet to be established. For much of the last century, scholars placed the ver$\operatorname{sion}(\mathrm{s})$ that we have today into the $3 \mathrm{rd} / 4$ th or even 5 th centuries. ${ }^{4}$ This rather late origin is no longer universally accepted since many connect the vinaya now with the Küśanā rulers of the second century CE. ${ }^{5}$ More material on taxation is included in the Pāli vinaya, in the Jatakas and in Buddhist narrative literature, but these do not add substantially to what we learn in the Mūlasarvāstivāda vinaya.

The commentaries upon this vinaya, most notably that by the 8th-c. monk Saakyaprabha, are the first to set out what one might call a systematic Buddhist strategy on tax liability. In the first instance, they draw on material found in the vinaya, but then proceed to align it with the tax policies developed in the brahmanical law books. This allowed the commentaries' authors to highlight bias in the law and rebut brahmanical claims to privilege. Much of their opposition to the existing revenue formulae sprang from the tax tariffs applied to donations. Any property offered to Buddhist monks, they argued, should be altogether tax exempt since, once handed over to the Sangha, it had left the world; such donations did not constitute commercial transfers but served to secure the spiritual advance of its donors. Their content had become, quite literally, priceless. It is not unexpected for an organization that relied for much of its start-up capital on the generosity of lay supporters to formulate such a position.

The Sangha's revenue coding and its calls for reform, coupled with the state's strict enforcement to contain repeat offending, suggest that the royal treasury had genuine reasons to worry about monastic tax compliance. The Sangha developed a series of strategies to avoid paying tax; some legal, other less so. Much of this resistance sprang from the rights and privileges that the state had granted to their contemporary Hindu ascetics who had been exempted from most forms of taxation. This created conflict. We do not know if the monks' protestations of discrimination generated any impact. The brahmanical law books of the later centuries contain no traces of any. They merely repeat the very principles first set out in the early dharmaśatras. In ancient India, it would seem, the calls of the Buddhists for tax reform achieved little in the end. In China, too, (as Palumbo discusses in this special issue), the Sangha remained liable to taxation, despite some concessions.

5 Schopen, Hierarchy and Housing in a Buddhist Monastic Code, 9; Schopen, Buddhist Monks and Business Matters, 20-21; Schopen, Learned Monk as a Comic Figure, 215. 


\section{The context of exemption}

The Vinayavibhanga of the Mūlasarvāstivāda vinaya contains evidence that, during the lifetime of the historical Buddha, his monks and nuns were exempt from payments of road tolls, customs duty and river crossing fees ${ }^{6}$ :

At one time, the Blessed One walked towards Śrāvastī amidst a forest [beset] with bandits in the company of King Bimbisāra of Magadha, 80,000 gods and a large number of brahmins and householders, also from Magadha, who had been established in the [four Noble] Truths. After [the Buddha] had converted Prasenajit, King of Kośala, with the Kumāradrstântasütra (D 296), the two, [king and queen], gave what the prince had left behind to the monks and what the retinue of the queen had left behind to the nuns. In that period monks were sent out without [fear of] duty payments, security fees or ferry tolls, and the teaching of the Blessed One spread [rapidly].

Our source does not reveal for how long this exemption lasted, nor does it disclose the ruler(s) who introduced it. If it was a local initiative, sponsored by the king of Magadha in north-eastern India, it would presumably not have reached significantly beyond his sphere of influence. Furthermore, the Vibhanga does not divulge the beneficiaries: did the privilege apply only to the Buddhists or was it extended to all traditions? It cannot have been very widespread. Another passage in the vinaya indicates that the general collection of customs duty together with transport and security fees had, by then, become commonplace in the North East:

The householder Anāthapiṇada asked: ,With the permission of the Blessed One, I wish to institute a festival of the stūpa of the Noble Saariputra.ı The Blessed One replied: >O householder, you may do it with my permission. ' When Prasenajit, King of Kośala, had heard how the Blessed One had permitted to institute the festival of the stupa of the Noble Śāriputra upon Anāthapindada's request, he thought: >This is excellent, I too shall help with this.< He then sounded the bell and declared: >Gentlemen, the city dwellers who live in Śrāvastī and the multitudes of people who have come together from other places, should listen: At the time when the festival of the Noble Śăriputra occurs, for those who have come bringing merchandise, there is no customs duty, no road toll or ferry toll. Therefore, they must be allowed to pass freely.< At that time, 500 overseas traders who had made a great deal of money from their ships arrived in Śrāvastī. They heard then how the king, sounding the bell in Śrāvastī, had ordered: >Whoever, at the time when the festival of the stūpa of the Noble Sảriputra takes place, comes bringing merchandise, for those there is no customs duty, no road toll and no ferry toll. Therefore, they must be allowed to pass freely here. ${ }^{7}$

These two passages indicate that in Kośala (in modern-day Uttar Pradesh) during the reign of Prasenajit (fifth century BCE), the state resorted to tax collection, as a fiscal instrument, to fund its administration. The kingdom's close political and economic ties to Magadha make it unlikely that the two would have adopted two radically different revenue systems.

6 Ca, 73r7-v2. Pagination to the Tibetan of the Mülasarvāstivāda vinaya refers to the sDe dge (Derge) bKa' 'gyur; see The Tibetan Tripitaka, ed. Barber. For quotations from the Dharmaśästras, I generally draw on the work of Patrick Olivelle whose command of this material is without parallel.

7 Kșudrakavastu, Tha, 246v3-247r1. 
In short, it is probably safe to assume that Magadha, just as Kośala, levied customs duty on goods in transit and charged travellers for the use of its highways and ferries, but issued on occasion exemptions to certain groups.

These records of early tax immunity preserved in the Buddhist monastic code have parallels in brahmanical literature. The law codes set out in its treatises of political science introduce a consistent and carefully calibrated set of principles of exemption. The third- or fourth-century Arthaśástra, most prominently, establishes that all goods transported for religious purposes escape taxation:

The following should pass without customs duty: [...] articles received on the occasion of a sacrifice, a religious ceremony, or a birth; articles for use in special rituals such as divine worship, tonsure, Vedic initiation, first shave and consecration for a religious observance. $^{8}$

Kautalya was not the only to issue tax privilege to the members of religious orders. Other sources put forth a similar immunity. The Apastamba Dharmasütra, too, exempts ascetic practitioners (tapasvin) from all revenue obligations:

The king should get [the security officers] to collect lawful taxes. The following persons are exempt from taxes: vedic scholars, women of all classes, pre-pubescent boys, those who are living in someone's house for the purpose of study, ascetics devoted to the Law (tapasvinaś ca ye dharmaparäh) [...] and those who are excluded from acquiring property. ${ }^{9}$

The Vasiștha Dharmasūtra, in turn, extends tax privileges for renunciants (pravrajita) to other members of society:

There is no tax (śulka) on [...] craftsmen, children, and messengers; on what is received as alms or what remains after a robbery; and on vedic scholars, wandering ascetics (pravrajita), and sacrifices. ${ }^{10}$

Further exceptions appear in the Mānava Dharmaśāstra and Vaiṣnava Dharmaśāstra. ${ }^{11}$ Both institute tax immunity to (pregnant) women, young boys, vedic students and renunciants prohibited from acquiring property. Some texts also broaden the privileges to include exemption from transportation fees at river crossings. The Vasiștha Dharmasütra contains a particularly detailed account:

The following [people] are exempt from tolls: vedic scholars, officials of the king, destitutes, wandering ascetics (pravrajita), children, old people, youngsters and new mothers as also couriers, young women and widows. If someone crosses a river swimming, he should be made to pay one hundred times the toll. ${ }^{12}$

8 Tibetan Tripitaka, ed. Barber, KA, 2.21.18.

9 Dharmasūtras, ed./trans. Olivelle, 2.26.9-17.

10 Dharmasūtras, ed./trans. Olivelle, 19.37.

11 Manu's Code of Law, ed. Olivelle, 8.407; Law Code of Viṣnu, ed. Olivelle, 5.131-132.

12 Dharmasūtras, ed./trans. Olivelle, 19.23-25. 
I cite these last few passages for the consensus they display. The views they articulate spring perhaps from a common source or direct borrowing from one another. But this does not compromise their value: the fact that their authors all agree on the same exemptions shows just how widespread these privileges had become.

The tax code(s) of the dharmaśästras offer immunity to those without ready access to wealth, in particular to practitioners of religion. Yet, they do not align well with the excise disputes preserved in the Mūlasarvāstivāda vinaya. That text records many episodes where Buddhist monks and nuns were required to pay customs duty. Initially, the Buddha is content to lay down the general principles that govern customs violations:

At a time when the Blessed One had realised the unsurpassed gnosis but had not [yet] spread the teaching, at the time when it was easy to rebuke monks but hard to rebuke householders, at that time a large group of monks travelled the country in the company of friendly merchants. When they had come to a customs office, the monks said to the merchants: >Respected Gentlemen, we have some goods that are liable to duty. So that the customs officers shall not begin to assess the duty [for those goods], could somebody smuggle [the goods] past the customs office and then give them [back to us]? ? The merchants replied: >Noble Sirs, we are happy to comply with your request and smuggle [the goods past the customs office].» The merchants then smuggled the monks' goods that were liable to duty past the customs office and gave them [back]. As the monks continued their journey, they arrived eventually at a vihära. Here a [local] monk greeted them: >Venerable Sirs, welcome, welcome. Did you travel well? Were you not harassed by customs officers (śaulkika), security forces (gaulmika) or ferrymen (tärapanyika)? The monks replied: ,Venerable Sirs, we travelled well and were not harassed by anybody.< The monk then enquired: >Did you not have any goods liable to duty? They replied: 'It is true, we had goods liable to duty but [our] merchant friends smuggled them past the customs office and then gave them [back to us].r The [local] monk replied: 'Is it fitting for you to evade arrival duty? ? They replied: 'Whether it be fitting or unfitting, that is the way in which we smuggled [our goods].« The monks then grew remorseful, fearing that they had exposed themselves to an offence leading to expulsion, and recounted in detail the incident to the [local] monks. Those, in turn, reported it to the Blessed One who declared: `O monks, those monks [here] are free from fault, but monks must not embark on the evasion of arrival duty. If they embark on the evasion of arrival duty, they come to be guilty of an offence. ${ }^{13}$

This passage is the first in our vinaya to recount a dispute at the customs office. But it also contains interesting detail about the status of monks and their proximity to the mercantile sector. First, it corroborates recent research which establishes that Buddhist monks (and nuns) were allowed to possess personal property, sometimes on a large scale. In this episode, their property was so substantial as to be liable to customs duty. Second, it sets out, beyond doubt, that the followers of the Buddha were expected to pay tax as they crossed administrative boundaries. This cannot be readily reconciled with the immunities offered to men of religion set out in the brahminical law books. Third, the monks asked a group of 
supportive merchants to help them smuggle their possessions past the customs office: they clearly feared close scrutiny of their baggage. This suggests that these monks and merchants travelled together or were very close, perhaps both. Finally, their local peers appear surprised when our travellers report that they enjoyed hassle-free travel and smooth passage through the customs point. To them, this was highly unusual: evidently Buddhist monks usually expected trouble when passing through customs.

\section{Categories of taxation in ancient India}

The brahmanical treatises of political science distinguish between six main forms of taxation: annual tribute paid on land (bali), tax on earnings (bhāga), income tax (veśya), sales tax (vanik), a special tax levied on top of the king's regular share (kara) and customs duty (sulka). The reach and content of these taxes is not always clear, even though they are all well attested in our sources. I shall now discuss, briefly, the most important fiscal instruments in ancient India.

First, let us examine bali. The Näradasmrti identifies bali as a synonym for bhāga: गThe king's revenue comes from another source called >one-sixth of the earth (bhumeh șadbhäga). ${ }^{14}$ This levy (bali) constitutes his wages for protecting his subjects.< The Vaisnava Dharmaśástra, in turn, describes bali as an annual tax payment that includes bhäga as well as several other levies:

From his subjects the king should collect as taxes (bali) every year a sixth portion of the grain, as also of all other crops; two percent of farm animals and gold, as also of clothes; and an eighth portion (ästabhäga) of meat, honey, ghee, herbs, perfumes, flowers, fruits, roots, juices, vegetables, leaves, skins, earthenware, stoneware, and wicker articles. ${ }^{15}$

Bhàga constituted a levy on earnings. It is often interpreted as the main tax and represents the king's share of all profits. Most sources speak of it as a sixth part of one's income. ${ }^{16}$ Bhagga was indexed to land. It was typically paid by peasants through agricultural produce. It was a universal tax that knew no exemption: 'Even forest dwellers, therefore, present one-sixth of their gleanings, with the thought: "This is the share of him who provides protection ${ }^{1}{ }^{17}$ The Mãnava Dharmaśästra offers the following definition of bhāga:

Of livestock and gold, the king shall take one fiftieth share (bhàga), and of grains, one eighth share, or a sixth or a twelfth. He shall also take a sixth share of trees, meat, honey, ghee, perfumes, herbs, condiments, flowers, roots, fruits, leaves, vegetables, grass, skins, cane, earthen vessels, and everything made of stone. ${ }^{18}$ 
The third type of tax is called kara. It is usually interpreted as a special, one-off, tax payment. ${ }^{19}$ This is also the view of the Arthaśästra: '[A demand for this tax (kara)] should be posed only once, not twice..$^{20}$ The Manāva Dharmaśästra, however, does not agree. It considers kara to be a tax specifically collected from merchants, at regular intervals throughout the year:

The king should levy taxes (kara) on traders after taking into consideration the price of purchase and sale, the distance of transport, maintenance of other expenses, and the cost of security. [...] As leeches, calves, and bees eat their food a little at a time, so a king should gather annual taxes (kara) from his realm a little at a time. ${ }^{21}$

I turn now to śulka. In essence, śulka is a tax imposed on movable property, charged at border crossings and administrative boundaries. In many ways, it corresponds to modernday customs duty. Manu, in his Manāva Dharmaśáśtra, explains that śulka is distinct from bali, bhäga and kara:

When he protects Vaiśyas with his weapons, [a Kșatriya] may collect a levy (bali) in accordance with the Law: from Vaiśyas, one-sixth share (bhāga) of the grain crop and a duty (śulka) of one-twentieth on other commodities, with a minimum of 1 kärșäpaṇa; from Súdras, artisans and craftsmen, the contribution of their services. ${ }^{22}$

The Vaiṣnava Dharmaśästra distinguishes between duty on domestic goods and duty on merchandise that has been imported:

The king takes as his share (bhäga) one sixth of the good and bad deeds of all his subjects. Furthermore, he should levy a duty (śulka) of ten percent on merchandise produced within his realm, and five percent on merchandise produced in a foreign country. ${ }^{23}$

These last few quotations, although useful for the rates they disclose, do not position sulka within the wider system of taxation. This is done in the Arthaśästra. The Arthaśastra is the first brahmanical law book to describe Indian state revenue collection in detail. It distinguishes between tax collected in the city and tax collected in the country. Many city levies were connected to trade and manufacture: (1) duty (ślka), (2) calibration fees (pautava), (3) payments to the director of the mint (lakșanādhyakșa) and (4) to the director of passports (mudrädhyakșa), (5) liquor tax (süra), (6) slaughter fees (sūnā), (7) fees resulting from the sale of ready-made goods (sütra, taila, ghrta, kșära), (8) penalty charges for the fraudulent manipulation of merchandise (panyasamsthā), (9) income tax (veśya), (10) gambling tax (dyūta), (11) property tax (vāstuka), (12) tradesmen tax (käru/śilpin) and (13) a gate levy (dväradeya). ${ }^{24}$ 
Country taxes are more diverse in nature. They were charged for services and produce: ${ }^{25}$ (1) levies collected from the king's own holdings $(s \bar{t} t \bar{a})^{26},(2)$ tax on the yield of private holdings (bhäga), (3) a special tax (kara), (4) sales tax (vanik), (5) payments to river guards (nadipāla), (6) fees for river crossings (tara), (7) hire charges for the use of government boats (nāva), (8) payments to guards stationed in coastal/riverside areas (pattana), (9) road tolls (vartanī) and (10) surveying fees (rajju).

In light of the reach of governmental tax collection, the Buddhist community did well to seek to protect its assets. As its members developed its economic interests - in large measure in close alliance with the mercantile sector - they identified strategies to argue for substantive exemptions. Some derived from tax privileges long held by their brahmanical peers, other focus on the non-commercial nature of the Sangha's wealth. It is to these claims that I shall turn next.

\section{Buddhist calls for tax exemptions}

Alarmed by the mounting demands at customs in response to the growing wealth of their monasteries, Buddhist legal experts began to draft proposals to effect changes in tax policy. In particular, they sought to influence the profile of the tax register and have certain items removed from it altogether. Predictably enough, they set out to secure tax immunity for those transactions that underpinned the wealth of their monasteries: the donations of their lay practitioners. The commentators sought this not only for property offered to the Buddha, Dharma and Sangha, but included goods gifted within the family unit of a monk. To them, religious donations constituted non-commercial property which should not be included in the tax register at all.

Most prominently, Śākyaprabha held that all goods, carried for reasons other than profit, should be exempt from tax. Initially, he envisaged such dispensation to apply only to the monks' utensils (upakarana), but soon came to include medicine, travel provisions and other items of daily use. He puts forth his arguments in the Mülasarvāstivādiśrämanerakārikāvrttiprabhāvatī:

>Merchandise is produced to be traded for a profit. Therefore [articles] which are not merchandise are not liable to duty. So, the utensils for living of ascetics should be recognized to be unsuitable for duty assessment. If the ascetics' utensils for living are nevertheless deemed liable to duty, one should under no circumstances embark on that particular journey. The authority on this is the [Vinaya]vibhanga where the [Buddha] forbids this, declaring: >One must never embark on a journey [with] articles liable to duty. ${ }^{27}$ 
Sákyaprabha then widens his call for immunity to all property that is not traded in business transactions:

Therefore, only [articles] produced for trade in the world warrant duty assessment, but other [goods] do not. The Blessed One said: ১Since the secular authorities consider a single woollen cloth to be of great value, because the ascetics' utensils for living are not liable to duty, you should ship it with your utensils [only] after you have turned it into a robe.< Well then, why did the Blessed One say: >In order to achieve exemption from duty [for the cloth], dip it into water or fray it; [only] then should you ship it«? He said this because he thought: 'Such [conduct] is without reproach. If customs officers spot multiple utensils, they become suspicious that these might be fit for duty assessment. It is not good if they then file charges.< Others hold that the Buddha said this in order to achieve duty exemption for [utensils] that have turned into merchandise. ${ }^{28}$

In this extract, the Buddha's view, as quoted, rests on the premise that mendicant utensils normally are not tax exempt. He therefore advises monks not to carry utensils in large volume: shipments of commercial scale will incur customs duty. Finally, the Buddha instructs his monks how best to sidestep all charges on new, unfinished cloth: make it look old.

Several monks heeded his advice to conceal the nature of their shipment at customs. The vinaya recalls an episode where a roll of uncut cloth lands a monk in conflict with the law:

The Buddha, Blessed One was dwelling in Śrāvastī, in the Jetavana, in the garden of Anāthapiṇdada. At that time, a certain monk was admitted to stay for the summer in Rajjagrha. After the three months of the summer had passed, without him acquiring a [new] robe [first], he set out for Śrāvastī to pay homage to the Blessed One. His [fellow] monks then advised him: ,Venerable Sir, better do not hurry away until you have obtained a [new] robe. When he did not stay because he resented [the delay], a monk gave him an uncut roll of cloth. He then thought: IIf [I] were to render this cloth permissible (run bar byed pa), I would not [have time to] see my fellow mendicants. Therefore, I shall have a friendly monk render it permissible. He then said to the friendly monk: /While I look up [some] fellow mendicants, please render this uncut roll of cloth permissible and put it into my bag. « Since [the friendly monk] was a lazy person, he did not render [the cloth] permissible but placed it directly into the bag. After the [first] monk had travelled [for a while], carrying the bag, he arrived eventually at a customs office. The officer said: >Noble Sir, do you have any goods that are liable to customs duty? ' >Respected Gentleman, I do not. >Please allow me then to carry out a search.< When the officer began to examine [his luggage] he spotted the cloth and said: >Noble Sir, you went forth to the well-spoken Dharma/Vinaya, so why do you lie to me for the sake of this uncut roll of cloth? ' The monk replied: >Respected Gentleman, I did not know [about it]. When I received this uncut roll of cloth on my departure, I said to a friend: "While I look up [some] fellow mendicants, please render this uncut roll of cloth permissible. Then put it into my bag." Since [my friend] is a lazy person, he did not render it permissible but placed it directly into my bag. The customs officer replied: 'Noble Sir, he is not your friend but, in this case, he is my friend. Therefore, please give to me [now] the customs duty that is due and leave. ${ }^{29}$ 
The passage does not explain what process turns an uncut or raw cloth into a permissible, tax-exempt cloth. Perhaps the cloth needed to be sewn into a robe to pass customs, or perhaps be soiled into a worn-looking rag. The term srender it permissibler (run bar byed pa) is not infrequent in the Mūlasarvāstivāda vinaya, mostly linked with rolls of cloth sewn into robes and the preparation of food. ${ }^{30}$

A little later, another vinaya commentator, Vinitadeva (c. eight cent.), draws on this and other passages to draft an overarching principle of exemption for Buddhist monks. His Triśatakärikāvyākhyāna says that property which lacks commercial value, personal possessions and goods belonging to others should be tax-free:

What sort of articles in particular are liable to customs duty? [Articles] that the secular authority has established to be of commercial interest, but not those intended for [personal] use, such as garments; what has been dedicated to others is not [liable to duty] either, nor is gold..$^{31}$

The Sangha argued for these exemptions to be extended to gifts and materials used in worship. Both of these mattered, since a large proportion of lay sponsorship reached the Sangha as offerings and ritual provisions. In the Vinayavibhanga, we encounter two episodes that flag up complications that derive from unguarded donations. ${ }^{32}$ The second discusses donations to the Sangha:

On his travels through the country, the monk prepared three bags filled with multicoloured cloth destined for the Buddha, Dharma and Sangha. After he had stayed for as long as he liked in the country, he took his begging bowl and cloak, and departed for Śrāvastì. After he had travelled for a while, he arrived eventually at a customs office. The tax officer said: `Noble Sir, do you not have any articles liable to customs duty? The monk replied: 'Respected Gentleman, I do not.` The customs officer then said: >Please allow me to inspect [your luggage]. $\ll$ When [the officer] began to examine [the luggage] of the monk and spotted three bags filled with multicoloured cloth, he said: 'Noble Sir, these three bags filled with multicoloured cloth may be small, but you are [still] required to pay duty as if they were to amount to a camel load.r The monk replied: 'Respected Gentleman, I am not the owner of these [bags]. ‘ Noble Sir, well then, to whom do they belong? > One belongs to the Buddha, one belongs to the Dharma and one belongs to the Sangha.' >Noble Sir, since I do not know either the Buddha, Dharma or Sangha, hand over the duty payment and leave. [ Since the monk could not pay,] the officer locked him up for a long time and then let him go. When the monk arrived eventually in Śrāvastī, he grew remorseful and told the [local] monks what had happened. They, in turn, reported it to the Blessed One who declared: >O monks, this monk is without offence, but he should not have gone about it in that way. He should have spoken a commendation of the Buddha, Dharma and Sangha in front of the customs officer. (At this point the Buddha gives a long laudatio of the Buddha, Dharma and Sangha.) If [the officer] lets him go after he has spoken such commendation of the Buddha, Dharma and Sangha, it is good. If he does not let him go, [the monk] should proceed to pay the customs duty. ${ }^{33}$

30 For instance, Tibetan Tripițaka, ed. Barber, Cha, 58v2-63v3, esp. 6or1- 61v2.

31 Tibetan Tripițaka, ed. Barber, Śu, 189r7-v1.

32 Tibetan Tripitaka, ed. Barber, Ca, 75v5-76v4; Ca 76v5-78r4.

33 Tibetan Tripitaka, ed. Barber, Ca, 77r2-78r1. 
This passage alerts us to an important aspect of tax liability: ownership. The monk argues that the rolls of cloth he carries in his luggage belong to the Buddha, Dharma and Sangha even though he has as yet to hand them over. The question of possession is not brought up at all (Ca, 77r5-6). Had the monk held papers linking the cloth to the Triple Jewel, he would, one imagines, been waved through. But perhaps our monk was simply unlucky. The officer did not recognize him as a follower of the Buddha and so failed to perceive the religious destination of the shipment; if he had, he might have acknowledged the immunity. Both ownership and provenance clearly mattered in tax law. Its treatises call for all goods, and especially those from abroad, to bear a stamp and be accompanied by transit papers that identify their owner, origin and destination (eg, KA, 2.21.2). Since the monk cannot produce any papers, the customs officer assumes the cloth to be his own.

Over time, as the donations it received grew in scale, the Sangha began to clamour for religious offerings, as a category, to be removed from the tax register. It stood to suffer significantly if the current regime was to be kept in place. Saakyaprabha was again the most outspoken critic of current practice:

The [Vinaya]vibhanga says: IIf [a monk] carries [goods] destined for the Triple Jewel or [his] parents, he should speak their praise [to avoid duty payment] or carry them after he has paid up. [This is so] because [the Buddha] said: 'When [a monk] pays [duty] on anything [he carries]<, he should realise that it is then identified to be [an article] that turned into merchandise. This is also possible since the Blessed One permitted it, saying: '[He] will carry [them] as merchandise.< If, however, [the articles] are not merchandise and he is under a lot of pressure at the time, since he is told that this precisely is customary for ascetics, he is under close scrutiny. The Buddha's statement: >After [a monk] who is under close scrutiny pays the duty<, should be understood as explanation because it is similar to a payment.

The authority on this is the *Mülavibhāsāa (rtsa ba'i bye brag tu bśad pa): sif [the articles] are [already] the property of a stüpa or Sangha, he should not defray duty from what it is that he has to carry destined for a stūpa or a Sangha. Why? Because [he] does not carry this as a means to conduct business. He should never take [anything] from those articles even though they may resemble merchandise. But why? [Because] he carries them in order to worship, not in order to make a profit. If [the articles] belong [already] to [his] teacher, preceptor, father or mother, he should not defray duty from what he carries destined for his teacher, preceptor, father or mother. Why? Because [he] does not carry them as a means to conduct business. He should never take [anything] from those articles even though they may resemble merchandise. But why? [Because] he carries them in order to worship, not in order to make a profit. They are gifts. For example, if one were to carry [a gift] to one region or another, [the monk] should not defray duty from that [gift]. Why? [It is as I said] before, ending in: »He carries [the article] as a gift, not to make a profit. « If it is an article of [general] use, he should never defray duty from what he carries for its use, whatever it may be. [It is as I said] before, ending in: "He carries [the article] for its use, not to make a profit. « ${ }^{34}$ 
For Śăkyaprabha, profit alone legitimates taxation. Goods that change hands outside a commercial framework do not generate income and should hence be exempted from tax. Donations to the Sangha yield spiritual merit, not financial return. Irrespective of their origin or appearance, they do not qualify as merchandise. The act of offering is completed the moment the donor resolves to carry out the donation, not at the point of transfer. As a result, goods intercepted at the customs house en route to the recipient no longer belong to the donor. He cannot be asked to pay tax for property that he no longer controls. ${ }^{35}$

Śakyaprabha calls for changes to the tax register; he does not incite to tax evasion. The Sangha understood the need to comply with the treasury's tax demands. In the vinaya, tax evasion features among the päräjika offences as a specific type of theft, punishable through permanent expulsion. Dharmamitra (c. 800), in his Vinayasütrațika (D4125), points out the dangers tax violations bring to the community: IIn order to avert a law-suit with the customs officers, etc., it is said that [monks] should not travel with [goods] liable to taxation. ${ }^{36}$ Gunaprabha, two centuries before him, already called for full compliance with the law:

Any property that is liable to duty, even if it is dedicated to the Triple Jewel or [to one's] parents, if the custom officer does not permit it, must be surrendered to customs. If it is not handed over [for tax assessment], it is a serious offence. ${ }^{37}$

\section{Status, power and religious aspirations}

Let us now step away from our Buddhist sources to explore their links to the religious and secular contexts within which their authors articulated their calls for tax exemption. Very early on, perhaps already during the lifetime of Śăkyamuni himself - if we can trust the later monastic codes - Buddhist mendicants came to be granted tax privileges. Initially, these exemptions were instituted for specific festivals, but already applied then to the mercantile sector. Merchants, we now know, enjoyed a particularly close association with the Sangha and played a major role in its rise to prominence in India, and beyond.

As the Sangha began to acquire ever increasing wealth, mainly through donations, it began to put in place measures to protect its assets. Chief among these were its efforts to secure tax exemptions at borders when its monks crossed from one administrative sector to another. The vinaya documents several instances of clandestine evasion, usually by individual monks and on a small scale. Without exception, its authors condemn all forms of tax violation, fearing legal repercussions for their peers and the community at large. Before long, however, they began to explore ways to minimize customs exposure, by making new goods look old, and the like.

But these constituted feeble responses to a much larger problem: with the steady increase of donations to the Sangha, in both volume and frequency, its tax liabilities began to rise to new levels. This would have affected the Sangha's treasury, to be sure. But more importantly perhaps, it would have soured its relationships with the donors who expected their entire

35 This argument is not without difficulty since the vinaya allows lay donors to retain a degree of control and ownership over their donations. This applies in particular, but probably not only, to donations of monastic property, such as temples, fittings and furniture. For several papers that touch on the topic of ownership of donations, see: Schopen, Buddhist Monks and Business Matters, in particular 219-259.

36 Tibetan Tripitaka, ed. Barber, 'U, $116 r 2$.

37 Tibetan Tripitaka, ed. Barber, Lu, 55r7-55v1. 
gifts to be available to the community to secure the highest possible merit in return. In short, the community needed to find a way to control its tax liabilities so as to protect existing assets and to retain its links to the lay sector for future donations. Its preoccupation shifted from tax disputes that involved individual monks to a more far-reaching challenge that would protect all donations from the probing eyes of the inland revenue.

It is difficult to pinpoint the moment when this challenge unfolded. The vinaya itself does not document any such effort. Discussions about the taxable status of donations appear first in the commentaries on the vinaya. Some of these were compiled in the 7 th century CE, others later still. They were written at a time when Buddhist monasteries in India approached the apex of their wealth and prestige; at a time when the Sangha would have been in unprecedented receipt of donations.

The arguments our commentators put forward in support of tax exemption for donations are very simple. First, donations do not constitute commercial transactions; they do not serve to generate income. As a result, they fall outside the tax register and should be exempted. It is not clear whether this contention ever gained traction. It is not documented outside Buddhist sources. While plausible and in line with contemporary tax theory, it does not appear in the premodern Indian tax treatises that I consulted for this study. Such a concession would have led to a significant loss of revenue for the state, in particular during the efflorescence of Buddhist monasticism (sixth to tenth centuries $\mathrm{CE}$ ).

Second, these commentaries argued that monks and nuns should be exempt from paying taxes because their brahmanical peers enjoyed this very status, and had done so for centuries. The vinaya commentaries call on the authority of the dharmaśasstras to give weight to this contention. It is true that practically all extant law books issue immunity from taxation to renunciants, from Manu to Kauṭilya. Apastamba (first cent. BCE?) ranks among the first to propose this exemption:

The king should get [the security officers] to collect lawful taxes. The following persons are exempt from taxes: vedic scholars, woman of all classes, pre-pubescent boys, those who are living in someone's house for the purpose of study, ascetics devoted to the Law [...] and those who are excluded from acquiring property. ${ }^{38}$

If brahmanical ascetics enjoy freedom from taxation, so should their Buddhist peers, the commentaries propose. Prima facie, this is a cogent stance since it calls for parity before the law. The devil is in the detail, though. While Buddhist and Brahmanical mendicants aspired to a similar soteriological goal and deployed cognate methods to achieve salvation, their personal circumstances could be very different. Buddhist monks were allowed to own personal property, and many did so. The monastic codes of all schools record instances where monks and nuns bring considerable private wealth to the Sangha, wealth which they continue to control even after ordination. As a result, at customs points, toll booths and river crossings, Buddhist monks constituted rich pickings. They would have been a lucrative source of revenue for the treasury. To be sure, not all monks enjoyed the privilege of wealth and few would have carried their possessions across boundaries, but those who did would have become welcome targets. 
The life of Brahmanical ascetics, in contrast, was governed by a strict code of renunciation and self-denial (see Kanad Sinha in this issue). Gautama, ${ }^{39}$ Vasișțha ${ }^{40}$ and Manu, ${ }^{41}$ all require religious mendicants to make do with minimal provisions: ${ }^{42}$

To achieve success, [the renunciant] must always wander alone, without any companions; recognizing that success comes to the solitary man, he will forsake no one and no one will forsake him. He should live without fire or house, enter a village to obtain food, be dispassionate, keep no store, and remain a silent sage and mentally composed. A [begging] bowl [to collect food], the foot of a tree [as lodging place], a ragged piece of cloth [as garment], a solitary life, and equanimity towards all - these are the marks of a renunciant.

A wandering ascetic should be shaven-headed, free from selfish yearning, and without possessions. He should go randomly to seven houses to beg for almsfood at a time when smoke is not rising from the kitchens and the pestles have been laid aside. He should wrap himself with a single piece of cloth or with an antelope skin. Covering his body with hay cut for the cows, he should sleep on the ground. Let him not keep a fixed residence, staying at the outskirts of a village, in a temple or an abandoned house, or at the foot of a tree. [...] Living always in the wilderness, let him never walk within sight of village animals. ${ }^{43}$

More importantly to us, the brahmanical ascetic was not allowed to engage in business transaction of any kind: '[...] Transactions (vyavahära) other than these shall not be valid, as also those executed by dependents [...], a notorious criminal, renouncer (pravrajita), cripple or someone who has fallen on hard times. ${ }^{44}$ According to Gautama, he even lost the right to ownership of property that had been taken away from others:

When others make use of the property of a person who is neither mentally incapacitated nor a minor before his very eyes for ten years, it belongs to the user, unless the user is a vedic scholar, a wandering ascetic (pravarjita), or a royal officer. ${ }^{45}$

Without access to substantive wealth of any kind, the brahmanical mendicant was of little interest to the tax collectors of the king. Poor, protected by the law and with no ties to the world, he easily navigated customs offices and toll stations on his travels. Not so the Buddhist monk. He often commanded personal wealth and was a member of an affluent organization that had erected monasteries across India and enjoyed close ties with the mercantile sector.

This prosperity propelled both the Sangha's pleas for tax exemption and the state's rebuttal of their claims. The followers of the Buddha sought to retain the community's wealth in order to maintain the monasteries it had built and expand its reach across the subcontinent.

39 Dharmasūtras, ed./trans. Olivelle, 3.11-25.

40 Dharmasūtras, ed./trans. Olivelle, 10.1-29.

41 Manu, Manu's Code of Law, ed. Olivelle, 6.33-60.

42 Manu, Manu's Code of Law, ed. Olivelle, 6.42-44.

43 Vasiștha, Dharmasūtras, ed./trans. Olivelle, 10.6-16.

44 Tibetan Tripitaka, ed. Barber, KA, 3.1.12.

45 Dharmasūtras, ed./trans. Olivelle, 12.37-38. 
Its lawyers, rather cleverly, drew on religious and cultural values that shaped Indian society at the time to legitimatize exemption. Buddhist monks called for tax immunity because they had long been granted to their Hindu peers; they considered them justified because they viewed all aspects of their activity religious, and hence beyond the remit of the state. Tax collection should not be allowed to compromise the scope of their institutional aspirations. The wealth that the monasteries had accumulated belonged ultimately to the Buddha. It sprang from the donations of their patrons in order to secure spiritual merit. The communities he founded put these resources to good use in order to safeguard the survival of his teachings. The property of the Sangha was thus quite divorced from lay aspirations of profit and power. Much of this property may have originally sprung from lucrative trade and shrewd investments, but once handed over to Buddhist communities, these links were severed. Now removed from society and the rules that govern it, just as the monks and nuns who managed the Sangha's wealth, the king had lost all claim to it.

The inland revenue disagreed with this interpretation. Its officers rejected the monks' claims to tax exemption. To them, the followers of the Buddha were fair game: mendicant or not. Their task was to appraise the value of the goods passing through customs, not the sanctity of their owners. 


\section{References}

Brucker, Egon, Wirtschaft und Finanzen im Staate Kautilyas unter besonderer Berücksichtigung der historischen und sozialen Verhältnisse. Unpublished $\mathrm{PhD}$ thesis (JuliusMaximilians-Universität zu Würzburg, 1966).

Dharmasütras: The Law Codes of Āpastamba, Gautama, Baudhyāna and Vaisisțha, ed. and trans. Patrick Olivelle (Delhi, 2000).

Gnoli, Raniero, The Gilgit Manuscript of the Sayanäsanavastu and the Adhikaranavastu: Being of the 15th and 16th Sections the Vinaya of the Mülasarvästivādin (Rome, 1978).

Lamotte, Etienne, History of Indian Buddhism: From the Origins to the Saka Era, translated from the French by Sara Webb-Boin, (Louvain, 1988).

The Law Code of Viṣnu: A Critical Edition and Annotated Translation of the VaisnavaDharmaśāstra, ed. and trans. Patrick Olivelle, Harvard Oriental Series 73 (Cambridge, MA, 2009).

Lévi, Sylvain, Les éléments de formation du Divyāvadāna, T'oung Pao, Second Series 8/1 (1907) 105-122.

Manu, Manu's Code of Law: A Critical Edition and Translation of the Mānava-Dharmaśästra, ed. and trans. Patrick Olivelle (New York, 2005).

The Näradasmrti: Critically Edited with an Introduction, Annotated Translation, and Appendices, ed. and trans. Richard W. Lariviere (Philadelphia, 1989).

Olivelle, Patrick, Dharmaśástra: A Textual History, in: Timothy Lubin, Donald R. Davis Jr. and Jayanth K. Kri- shnan (eds.) Hinduism and Law: An Introduction (Cambridge, 2010) 28-57.

Pagel, Ulrich, Buddhist Monks in Tax Disputes: Monastic Attitudes towards Revenue Collection in Ancient India, Buddhist Asia 3, Universita degli studi di Napoli "L’Orientale« (Napoli, 2014).

Scharfe, Hartmut, Investigations in Kauțalya's Manual of Political Science (Wiesbaden, 1993).

Schopen, Gregory, Hierarchy and Housing in a Buddhist Monastic Code: A Translation of the Sanskrit Text of the Sáyanāsanavastu of the Mülasarvāstivāda-vinaya - Part One (from the Sanskrit), Journal of Buddhist Literature 2 (2000), vol. 2, 92-195.

Schopen, Gregory, Buddhist Monks and Business Matters: Still More Papers on Monastic Buddhism in India (Honululu, 2004).

Schopen, Gregory, The Learned Monk as a Comic Figure, Journal of Indian Philosophy 35 (2007) 201-226.

The Tibetan Tripițaka. De dge (Derge) bKa' 'gyur, ed. Anthony W. Barber (Taipei, 1991). 